\title{
Delayed effects of prey fish quality and winter temperature during the birth year on adult size and reproductive rate of Baltic grey seals
}

\author{
Kaarina Kauhala $^{1}$ (D) Mika Kurkilahti $^{1}$ \\ Received: 11 April 2019 / Accepted: 22 August 2019 / Published online: 10 September 2019 \\ (C) The Author(s) 2019
}

\begin{abstract}
Environmental conditions of mammalian juveniles may have delayed effects on their life histories and fitness, such as body size or reproductive rate later in their lives. In the present study, we tested this hypothesis on Baltic grey seals (Halichoerus grypus) and examined (1) the possible effects of prey fish quality and winter temperature on body condition of grey seal pups of both sexes and (2) the possible delayed impacts of pup environment on the body size and birth rate of adult grey seals. Body condition (blubber thickness) of especially female pups in April-May correlated negatively with winter temperatures, and body condition of male pups correlated positively with prey fish quality (herring Clupea harengus and sprat Sprattus sprattus weight). Males reached the asymptotic length at the age of 10.3 years, and body length of adult males ( $\geq 10$ years old) was positively related to herring and sprat weight in their birth year. Females reached the asymptotic length at the age of 5.9 years. Birth rate of females (age 7-24 years) was negatively related to winter temperature in their birth year. We conclude that both changes in prey fish quality and climate may affect body condition of pups and thus also cause delayed effects on adult fitness: body size and reproductive rate of Baltic grey seals.
\end{abstract}

Keywords Birth rate $\cdot$ Body length $\cdot$ Blubber thickness $\cdot$ Climate $\cdot$ Halichoerus grypus $\cdot$ Herring

\section{Introduction}

Environmental conditions and early growth of mammalian juveniles may have delayed effects on their life histories and fitness, such as body size or reproductive rate later in their lives (e.g. Clutton-Brock et al. 1982; Lindström 1999; Beckerman et al. 2002; Helle et al. 2012; Bowen et al. 2015). For instance, bank voles (Myodes glareolus), which were supplemented by extra food as juveniles, produced larger litters and bigger pups than those which were not supplemented with food (Helle et al. 2012). Both food resources and weather experienced by young female of

Communicated by: Cino Pertoldi

Kaarina Kauhala

kaarina.kauhala@luke.fi

Mika Kurkilahti

mika.kurkilahti@luke.fi

1 Natural Resources Institute Finland, Luke, Itäinen Pitkäkatu 4 A, FI-20520 Turku, Finland
North American red squirrels (Tamiasciurus hudsonicus) affected their reproductive success (Descamps et al. 2007). Conditions early in life also influenced lifetime reproductive success of European rabbits (Oryctolagus cuniculus; Rödel et al. 2009). Population density and food availability affected juvenile size and the age of sexual maturity in harbor porpoises (Phocoena phocoena; Read and Gaskin 1990). Environmental circumstances, which affect maternal condition of nursing female seals and thus indirectly size and body condition of their pups, may have delayed effects on the future phenotype and fitness of pups (e.g. Garrott et al. 2011). Growth conditions of juveniles may also influence reproductive rate of other animals, such as fish (Taborsky 2006) and birds (Reid et al. 2003). Long-lasting cohort effects can be seen even in humans (e.g. Lummaa and Clutton-Brock 2002).

The juvenile environment may have different delayed effects on males and females especially in polygynous mammals with sexual size dimorphism (Clutton-Brock et al. 1982). When males are much bigger than females and therefore grow faster, early growth may have a stronger effect on the size of adult males than that of adult females. Body condition or size of 
female pups may have an influence on their future reproduction (Boyd et al. 1999; Bowen et al. 2015).

Grey seal (Halichoerus grypus) is a top predator in the Baltic Sea. It is a generalist predator preying on several fish species (Lundström et al. 2007, 2010; Kauhala et al. 2011; Scharff-Olsen et al. 2018; Tverin et al. 2019). In the Finnish sea area, Baltic herring (Clupea harengus membras) is the most common prey fish for grey seals, and herring quality is related with body condition and reproductive rate of seals (Kauhala et al. 2016, 2017, 2019). Another common prey fish for grey seals is the sprat (Sprattus sprattus), especially in the southern part of the Finnish sea area (Kauhala et al. 2011). Changes in the Baltic food web which influence the populations of the prey fish species of seals (Casini et al. 2006, 2008, 2010) also have demonstrable effects on seal populations (Kauhala et al. 2016, 2019).

Climate change may also affect seal populations. Decline in sea ice during breeding season has a negative influence on both ringed (Pusa hispida) and grey seals (Jüssi et al. 2008; Ferguson et al. 2017). Grey seals in the northern Baltic Sea usually give birth on drift ice in February or March and nurse their pups about 3 weeks (Kauhala et al. 2014). In warm winters when there is no ice in their breeding areas, grey seal females are, however, forced to breed on land, usually on small islets. On drift ice females with their pups are scattered but on small islets they are packed and nursing may be disturbed by other seals and pathogens may spread easily. This may be the reason why pups born on land are leaner at weaning than pups born on ice (Jüssi et al. 2008).

The aim of the present study was to test the hypothesis that growth conditions of pups have delayed effects on adult seals. We examined (1) the possible effects of prey fish quality and winter temperature on body condition of grey seal pups of both sexes and (2) the possible delayed impacts of prey fish quality and winter temperature at the birth year of grey seals on body size and reproductive rate of adult seals.

\section{Material and methods}

\section{Study area and seal samples}

Grey seal samples were collected from the Finnish sea area in the ICES subdivisions 29-32 between 1999 and 2018 (Fig. 1). Samples were mainly collected from hunters, but also fishermen sent samples of seals bycaught in fishing gear. Hunting season is from 16 April to 31 December (except in Åland to 31 January). Seals were hunted during regular hunt. No seals were killed for this study.

Seal samples included at least the lower jaw, genital organs (baculum or uterus and ovaries) and liver. Seal species was confirmed from the lower jaw and sex from genital organs. Histological slides were made from the cementum of lower

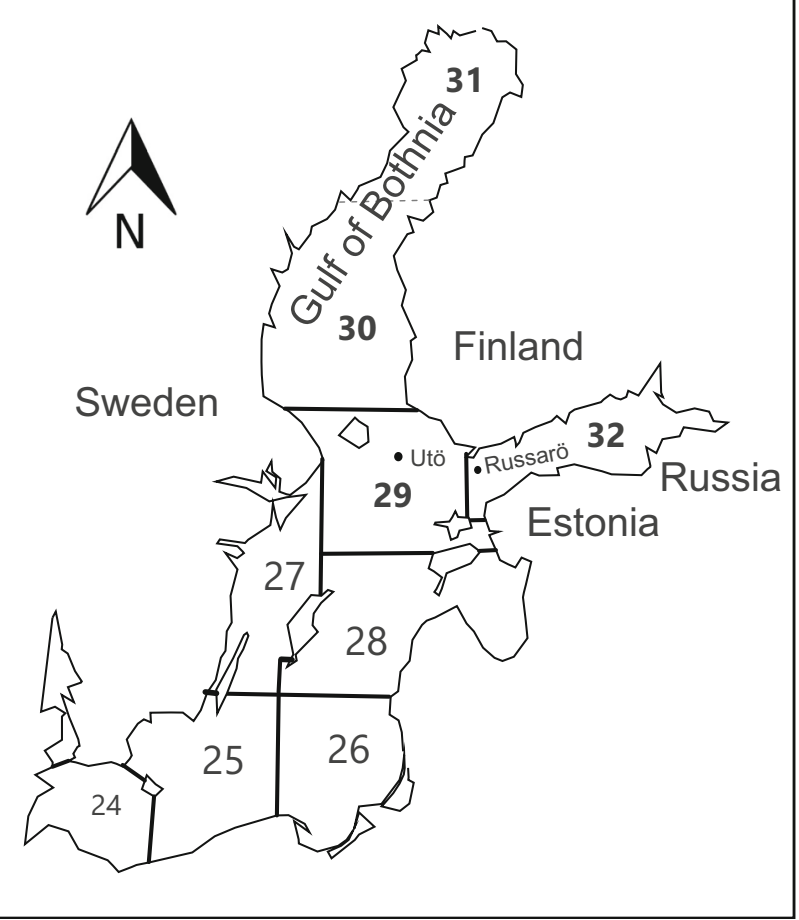

Fig. 1 Grey seal samples were collected from the Finnish sea area from ICES SD 29-32. 29 = Archipelago Sea, $30=$ Bothnian Sea, $31=$ Bothnian Bay, 32 = Gulf of Finland. Two small islands (Utö and Russarö) are also shown

canine teeth, and age of seals was determined from incremental lines in the cementum (Mansfield 1991). Age determination was done and compared by two experienced persons to minimize the risk of erroneous results. Furthermore, pups were killed in spring and were thus small and easy to identify.

Age was expressed in years with decimals, based on the assumption that seals were born the 1st of March (in Finland the pupping season is usually from mid-February to midMarch). Seals less than 1 year old were called pups because all were killed in April and May in the year of birth. Body length was measured from the tip of the nose to the tip of the tail (to the nearest $\mathrm{cm}$ ) from 533 seals in 2003-2018, and 398 seals were weighed (when possible) in 1999-2018 or the weight was estimated by hunters because it was not always possible to weigh big seals. Subcutaneous blubber thickness was measured at the sternum from skin to muscle (to the nearest $\mathrm{mm}$ ) from 58 pups from 2011 to 2018 (for details, see Kauhala et al. 2017).

Ovaries were removed, and cross sections made by knife were examined by naked eye for the presence of corpus albicans (CA). Birth rate was determined as the proportion of females with CA from the spring sample (April-June; see also Kauhala et al. 2014, 2016). Corpus luteum atrophies to CA after parturition and remains until mid-summer when a new embryo implants into the uterus but may disappear after mid-summer if the female is not pregnant (Hewer 1964; Boyd 
1984). Therefore, only the spring data were used to calculate birth rate the present year. Birth rate was confirmed from placental scars in the uterus (Kauhala et al. 2014). Only few females reproduce before the age of five, and birth rate of 5-6year-old females (or pregnancy rate of 4-5-year-old in autumn) is lower than that of older females. Birth rate declines after the age of about 25 years (Kauhala et al. 2014). Therefore, birth rate of the age group 7-25 years $(n=466)$ was tested here.

\section{Environmental variables}

The quality of food resources was calculated as the mean individual weights of herring and sprat for 5 years old and older fish (age group 5+), because seals do not usually prey on smaller fish (Lundström et al. 2007; Gårdmark et al. 2012). Fish data was obtained from the report of ICES (ICES 2018). Herring data were from two areas: from the Gulf of Bothnia (ICES SD 30 and 31) and from the southern sea area (ICES SD 25-29 and 32; Fig. 1), and sprat data were from the southern sea area. Fish stocks in the southern sea area of Finland are considered part of a wider stock, and the data from these areas are pooled in ICES reports.

Winter temperatures were the mean air temperatures from January-March in Russarö and Utö, two small islands in western Gulf of Finland (Russarö) and in the Archipelago Sea (Utö) from which long time series data were available. In the Finnish sea area, grey seals usually give birth on drift ice in the outer archipelago, so winter temperatures on these islands can be compared with birth rate in the Finnish data of grey seals. Winter temperature correlated negatively with the number of days with ice cover from 2002 to 2015 (Russarö: $r=-0.94$, $p<0.001$; Utö: $r=-0.88, p<0.001)$. Winter temperatures were used here because, unlike ice data, temperature data for the whole study period were freely available in the web pages of the Finnish Meteorological Institute (https:// ilmatieteenlaitos.fi/havaintojen-lataus\#!/).

\section{Statistical tests}

The possible effects of winter temperature and food quality (herring and sprat weight) on the blubber thickness of male and female pups were tested with correlation and regression analyses. We used only hunted pups because bycaught seals are usually leaner than hunted seals (Bäcklin et al. 2011; Kauhala et al. 2015). Because most pup data $(n=58)$ were from the Gulf of Finland, we compared the blubber thickness of pups from the Gulf of Finland in April and May (no data from January-March) with winter temperatures in Russarö and Utö and herring weight in the southern area. We also calculated correlations between blubber thickness and body length separately for male and female pups.
Growth in body length and weight over the seals age was estimated by using the von Bertalanffy growth function (VBGF; McLaren 1993). However, we used a different parameterization of the model and estimated, instead of $t_{0}$ (time point when the growth started, negative value), the size of newborn pups at birth (Cailliet et al. 2006):

$L(t)=L_{\infty}-\left(L_{\infty}-L_{0}\right) e^{-k t}$,

where $L(t)$ is body length as a function of time $(t), L_{\infty}$ is the theoretical asymptotic length (full size), $L_{0}$ is the size at birth, and $k$ is the rate constant. Year classes from 0 to 25 were included in the model.

The seal's age at which the $95 \%$ level of $L_{\infty}$ was achieved was estimated from equation:

$\operatorname{Age}_{95 \% L_{\infty}}=\left(\frac{1}{k}\right) \times\left\{\ln \left[\left(L_{\infty}-L_{0}\right) /\left((1-0.95) \times L_{\infty}\right)\right]\right\}$.

Differences between sexes for $L_{0}, L_{\infty}, k$ and $\mathrm{Age}_{95 \% L_{\infty}}$ were estimated from the models above by replacing $L_{\infty}$ with $\left(L_{\infty}\right.$ female $+\left(L_{\infty}\right.$ difference $\times$ sex $\left.)\right)$ where sex was a class variable. Nonlinear model fitting was done with SAS 9.4 (PROC NLIN and PROC NLMIXED) and is described in more detail in Auttila et al. (2016).

The possible effects of independent variables, i.e. sea area, cause of death (hunted vs. bycaught) and the seals' birth year, on body length and weight of grown-up (from age of 95\% asymptotic size) male and female seals, were tested with general linear model (normal distribution, identity link, GLM, software Systat 13). A stepwise backward procedure was used excluding the non-significant independent variables one at a time, the one with the highest $p$ value first. Only variables which significantly increased the $r^{2}$-values were included in the models. The level of significance was set to 0.05 . However, AICC-values (AIC corrected) were also taken into account in cases when there was a variable with $p$ value between 0.10 and 0.05 , and the final model was chosen according to the lowest AICC-value. Normality of residuals was tested with one-sample Kolmogorov-Smirnov (K-S) test. In cases when residuals were not normally distributed according to K-S test, also KruskalWallis analysis of variance $(\mathrm{K}-\mathrm{W})$ was done.

In cases when birth year of seals significantly affected body length, correlation and regression analyses were carried out to reveal possible connections between body length of adults (body length $\geq$ asymptotic length) born in different years and the environmental variables (herring and sprat weight and winter temperature) at the birth year of seals. We also calculated birth rate according to the birth year of females, i.e. different cohorts of females. We then calculated correlation and regression analyses to reveal the possible connections between birth rate and the 
environmental variables at the birth year of females. Annual values for birth rate were smoothed with 3-yearmoving average due to small sample sizes for some years.

\section{Results}

\section{Blubber thickness of grey seal pups}

Blubber thickness of hunted pups in the Gulf of Finland in April-May ( $n=58: 31$ males and 27 females) declined during the study period $\left(r^{2}=0.13\right.$, slope $=-1.43, F=8.2, d f=1,56$, $p=0.006$; Fig. 2a). There was a negative relation between winter temperature and blubber thickness (Fig. 2b).

Average blubber thickness of hunted pups in April-May from the Gulf of Finland correlated negatively with winter temperatures in Russarö and Utö from 2011 to 2018 (Russarö: $r=-0.81, p=0.026$; Utö: $r=-0.79, p=0.036$ ). When the sexes were tested separately, the correlation between winter temperature and blubber thickness was significant only for females (females: Russarö, $r=-0.87, p=0.012$; Fig. 2b; Utö: $r=-0.85, p=0.015$; males: Russarö: $r=-0.47$, NS; Utö: $r=-0.43$, NS).

Average blubber thickness correlated positively with herring weight (southern area) from 2012 to 2017 ( $r=0.98, p=$ $0.003)$. When sexes were treated separately, blubber thickness of only male pups correlated significantly with herring weight (males: $r=0.95, p=0.012$; females: $r=0.81, p=0.096$ ). No significant correlations existed when a time-lag of 1 year was included (herring weight from the previous year). Furthermore, blubber thickness and body length of male pups (all pups from the Gulf of Finland included) correlated positively $(r=0.49, p<0.001, n=50)$. No significant correlation was found between blubber thickness and body length of female pups $(r=0.16, p=0.283, n=47)$.

\section{Body length of grey seals}

The asymptotic length of males $(n=253)$ was $206 \mathrm{~cm}$, and males reached $95 \%$ of the asymptotic length at the age of 10.3 years (Fig. 3, Table 1). The asymptotic length of females $(n=280)$ was $170 \mathrm{~cm}$, and females reached $95 \%$ of the asymptotic length at the age of 5.9 years.

Only the year of birth significantly affected the body length of grown-up ( $\geq 10$ years old) males $\left(r^{2}=0.47, F=2.2, d f=22\right.$, $55, p=0.009, n=78)$. The mean body length decreased as a function of the year of birth during the study period, being on average $214 \mathrm{~cm}(\mathrm{SD}=15.8, n=13)$ in the $1980 \mathrm{~s}$ and $193 \mathrm{~cm}$ ( $\mathrm{SD}=7.6, n=21$ ) in the 2000s (Fig. 4a). Average length of grown up males correlated positively with the mean weights of herring (Gulf of Bothnia: $r=0.55, p=0.008, n=22$; southern areas: $r=0.54, p=0.009)$ and sprat $(r=0.61, p=0.003)$ at the birth year of seals (Fig. $4 \mathrm{~b}$ and c). Male seals born in years when the mean weights of herring and sprat were low were shorter as adults than those born in years when the mean weight of fish was high.

Only sea area significantly affected body length of grownup females ( $\geq 5$ years of age; $r^{2}=0.16, F=10.3, d f=3,165$, $p<0.001)$. Females were longest in the Gulf of Finland (174 cm, $S E$ 3.37, $n=34$ ) and shortest in the Bothnian Sea $(160 \mathrm{~cm}, S E=5.25, n=14)$.

\section{Body weight of grey seals}

The asymptotic weight of males $(n=198)$ was $179 \mathrm{~kg}$, and $95 \%$ of the asymptotic weight was reached at the age of 18 years (Fig. 5, Table 1). The asymptotic weight of females
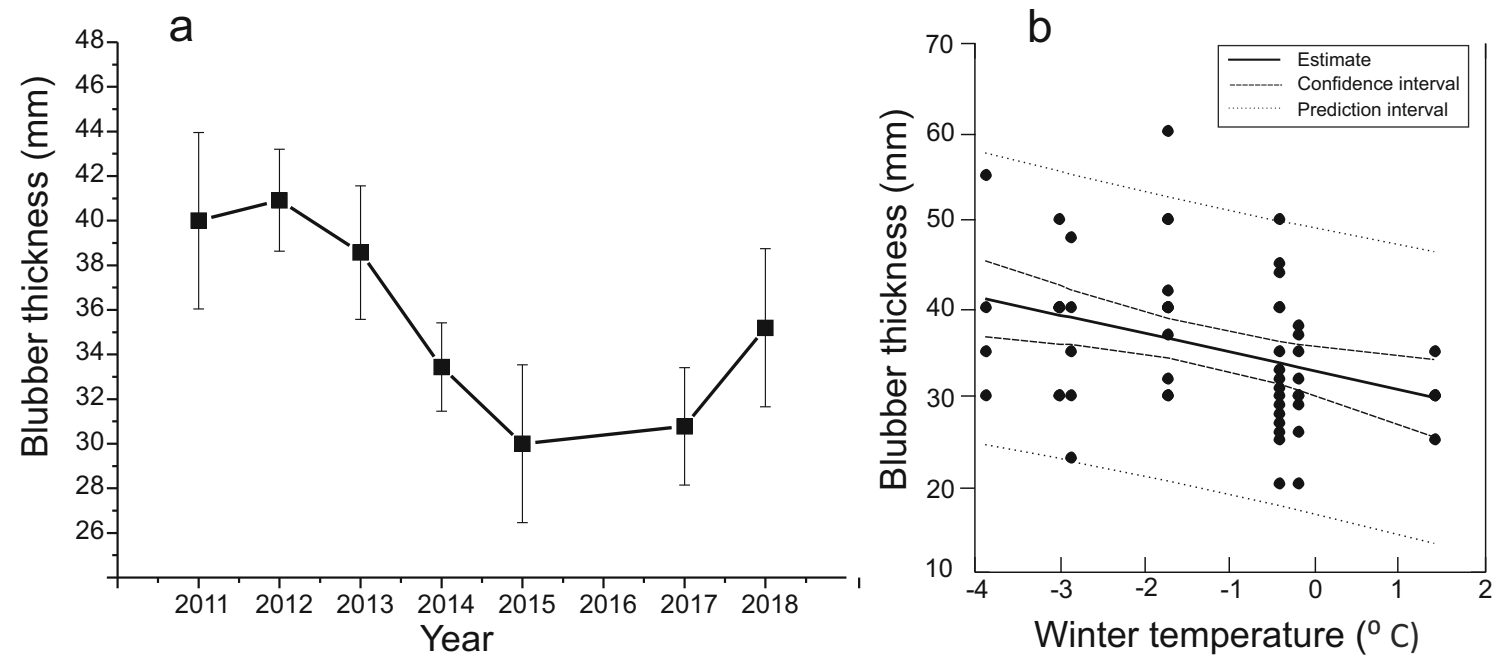

Fig. 2 Blubber thickness of hunted pups (mean and SE; $n=58$ ) in April-May in the Gulf of Finland from 2011 to 2018 (no data in 2016 ; a), and the relation between winter temperature in Russarö and blubber thickness of pups $\left(r^{2}=0.13, F=8.7, d f=1,56, p=0.005 ; y=32.795-2.141 x ; \mathbf{b}\right)$ 
Fig. 3 Asymptotic growth curves (body length) for male (a) and female (b) grey seals showing the ages when $95 \%$ of asymptotic length was reached. Difference between sexes at age when $95 \%$ of maximum length is achieved is 4.4 years $(95 \% \mathrm{cl} 1.8-7.1, p=$ 0.001 ). Grey area shows $95 \%$ confidence intervals of the mean, and dotted lines show 95\% prediction area for individual observations a

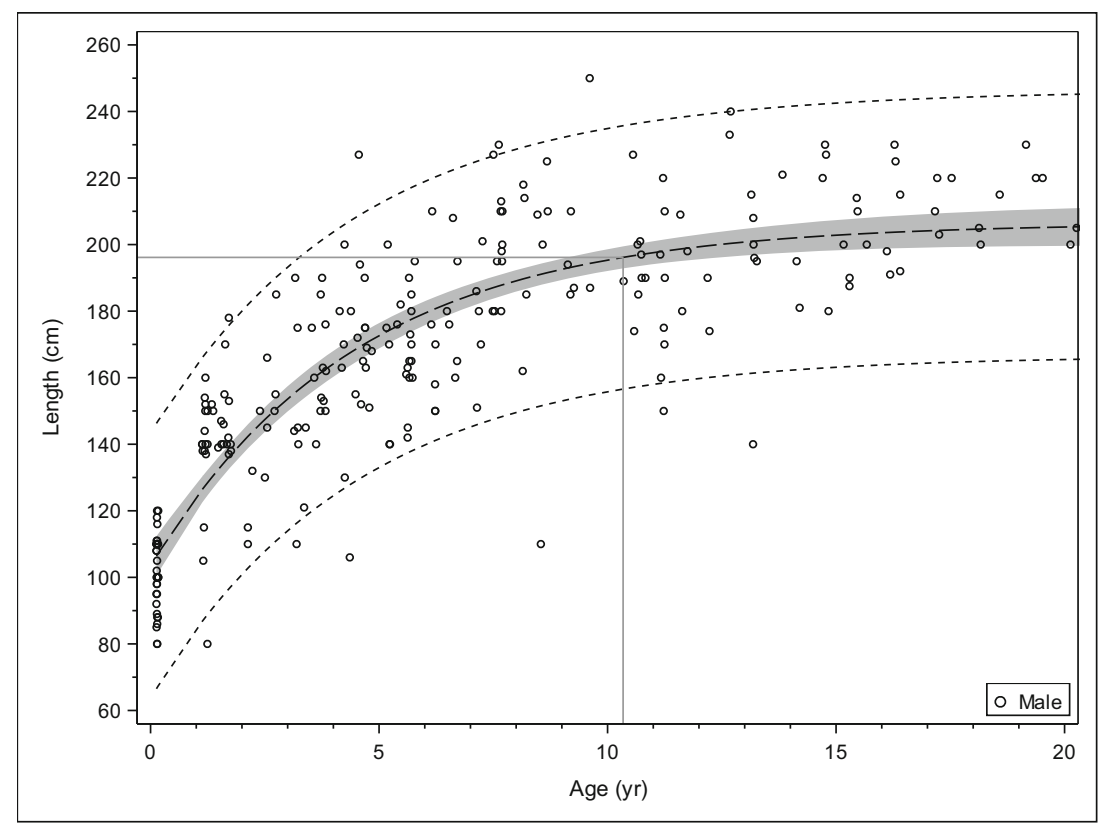

b

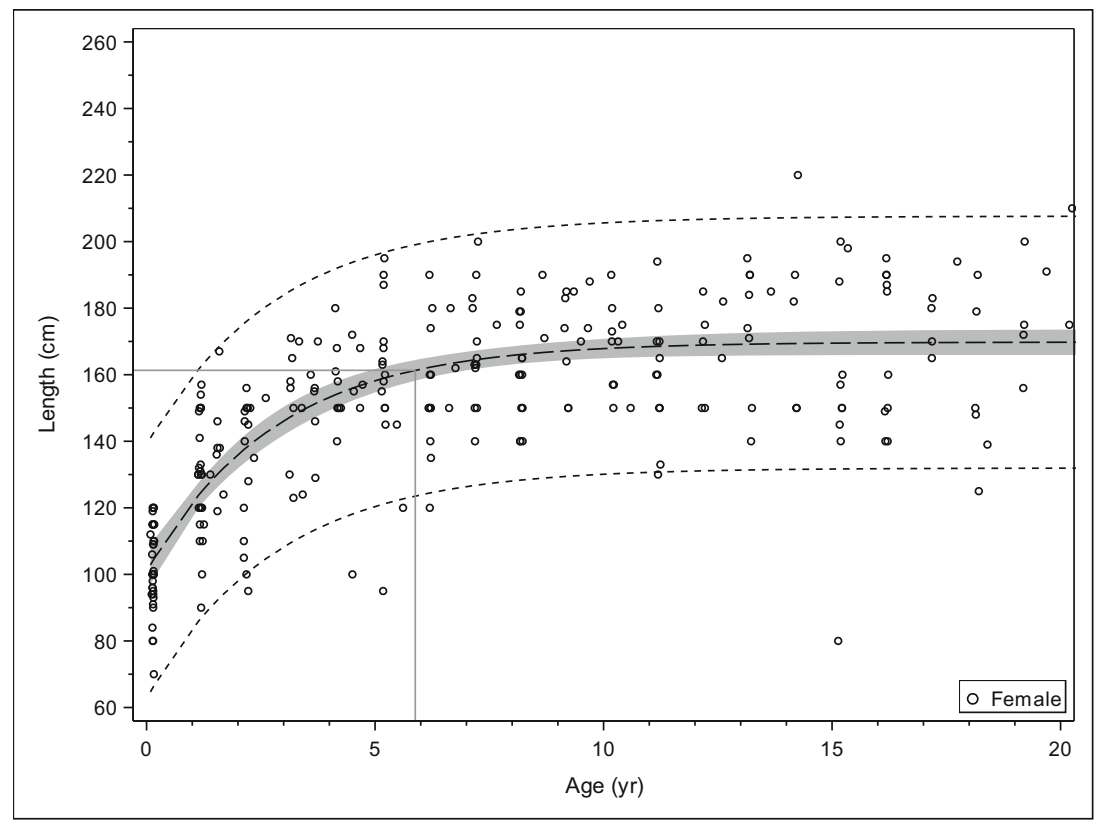

Table 1 Estimated asymptotic size of body length (cm) and weight ( $\mathrm{kg}$ ) and age (years) when they have achieved $95 \%$ of the asymptotic size

\begin{tabular}{lllllcc}
\hline Parameter & Sex & $n$ & $\begin{array}{c}\text { Asymptotic } \\
\text { length }(S E)\end{array}$ & 95\% conf. limits & \multicolumn{2}{c}{$\begin{array}{l}\text { Age of 95\% asymptotic } \\
\text { size }(S E)\end{array}$} \\
\hline Length $(\mathrm{cm})$ & Male & 253 & $206(3.3)$ & $200-213$ & $10.3(1.1)$ & $8.3-12.4$ \\
& Female & 280 & $170(2.1)$ & $166-174$ & $5.9(0.8)$ & $4.3-7.5$ \\
Weight $(\mathrm{kg})$ & Male & 198 & $179(7.7)$ & $164-194$ & $18.0(2.3)$ & $13.3-22.6$ \\
& Female & 200 & $120(4.4)$ & $111-128$ & $10.7(2.0)$ & $6.9-14.6$ \\
\hline
\end{tabular}



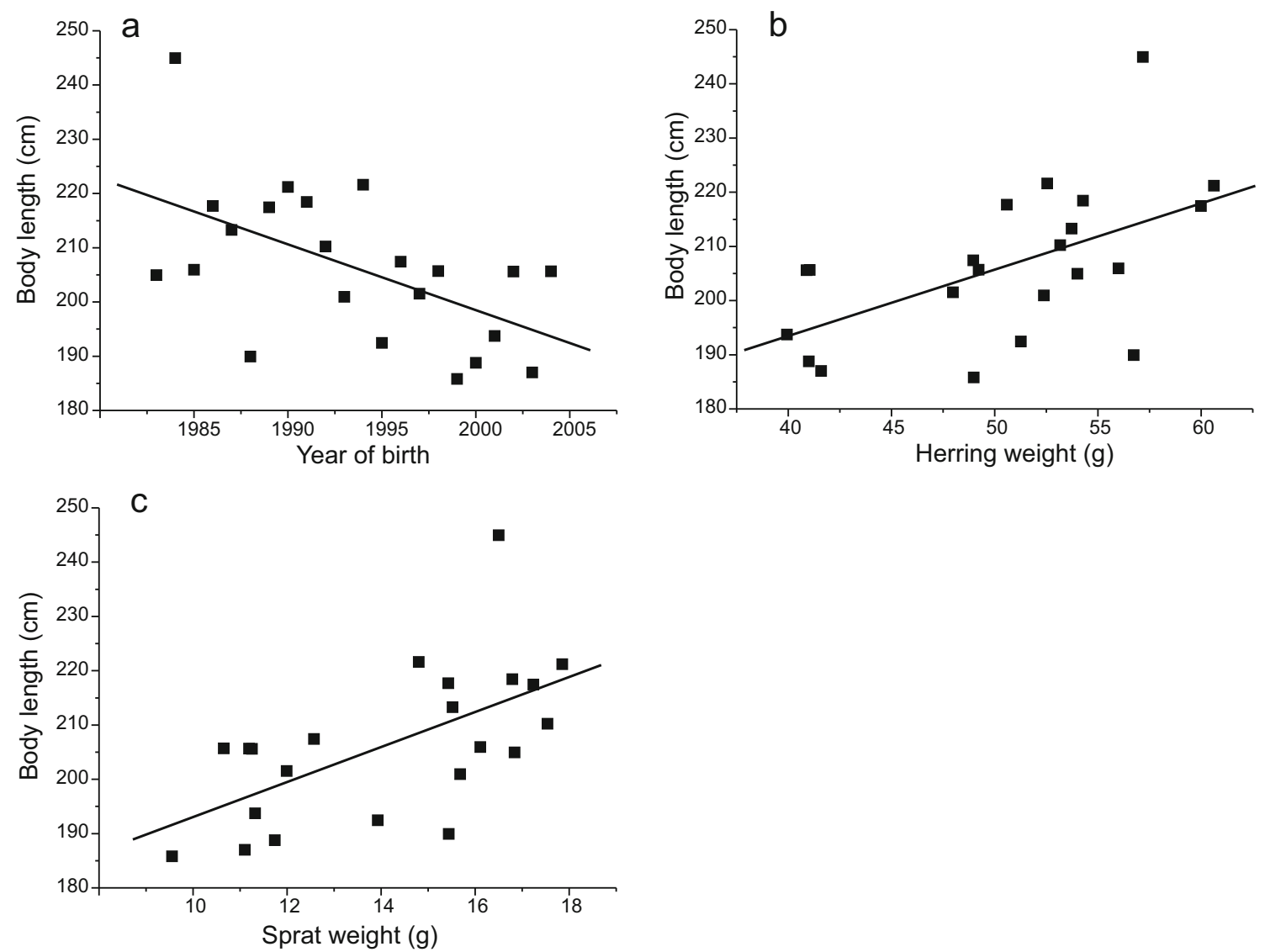

Fig. 4 Mean body length of $\geq 10$-year-old males as a function of the birth year of seals from 1983 to $2004\left(r^{2}=0.31, F=9.0, d f=1,20, p=0.007\right.$; $y=2622.519-1.212 x$; a), the mean weight of herring in the Gulf of Bothnia in the birth year of seals $\left(r^{2}=0.30, F=8.5, d f=1,20, p=\right.$

$0.008 ; y=144.444+1.225 x ; \mathbf{b})$ and the mean weight of sprat in the birth year of seals $\left(r^{2}=0.37, F=11.5, d f=1,20, p=0.003 ; y=\right.$ $160.766+3.227 x ; \mathbf{c})$

( $n=200)$ was $120 \mathrm{~kg}$, and $95 \%$ of the asymptotic weight was reached at the age of 10.7 years. None of the variables (birth year, sea area or cause of death) affected the body weight of grown-up male or female seals.

\section{Reproductive rate of grey seal females}

The effect of age on the birth rate of females 7-25 years old $(n=466)$ was first tested. Age significantly affected birth rate of 7-25-year-old females (logistic regression: $\operatorname{chi}^{2}=4.17, p=$ 0.041 ), but age was not significant when 25 -year-old females were excluded $\left(c h i^{2}=1.22, p=0.268\right)$. Therefore, the age group of 7-24 years was used $(n=460)$. The mean birth rate (2001-2018) was 79\% for 7-24-year-old females, and was lower (mean 56\%) for younger females (5-6 years old, $n=$ 66) during the study period.

Birth rate of females born between 1983 and 2002 correlated negatively with winter temperature in their year of birth (Utö: $r=$ $-0.49, p=0.027$; Russarö: $r=-0.48, p=0.032$ ). Birth rate of females born in the warm winters in the early 1980s and the early 1990s was $72-77 \%$, whereas birth rate of females born in the cold winters in the mid-1980s and the mid-1990s was $82-85 \%$

(Fig. 6). No correlation between birth rate and winter temperature of the birth year existed after 2002 (but the sample sizes of the last years were small; Appendix in Table 2). There were no significant correlations between birth rate of females and herring or sprat weight in their birth year $(p>0.050)$.

\section{Discussion}

Body condition of pups in the Gulf of Finland declined during the study period and was related to winter temperatures and food quality (herring weight). There were, however, differences between sexes: food quality was positively related to blubber thickness of especially male pups, whereas winter temperature was negatively related to blubber thickness of female pups. The reason behind different results for male and female pups is not clear but may be due to the small sample sizes. It is probable that the effects of prey fish quality and winter temperature are similar for pups of both sexes. However, blubber thickness and body length correlated only in male pups, suggesting that body condition has a stronger effect on the growth rate of male pups. 
Fig. 5 Asymptotic growth curves (body weight) of male (a) and female (b) grey seals showing the ages when $95 \%$ of asymptotic weight has been reached.

Difference between sexes at age when $95 \%$ of maximum weight is achieved is 7.3 years $(95 \% \mathrm{cl} 1.3-$ $13.2, p=0.018)$. Grey area shows $95 \%$ confidence intervals of the mean, and dotted lines show $95 \%$ prediction area for individual observations a

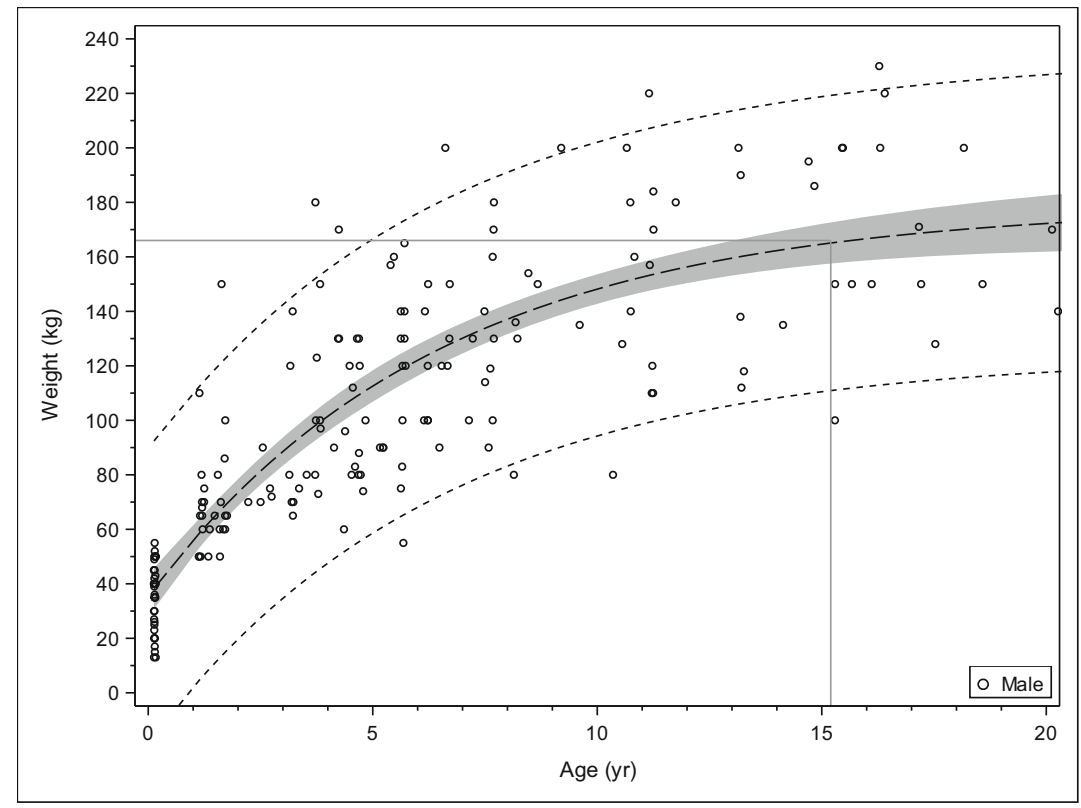

b

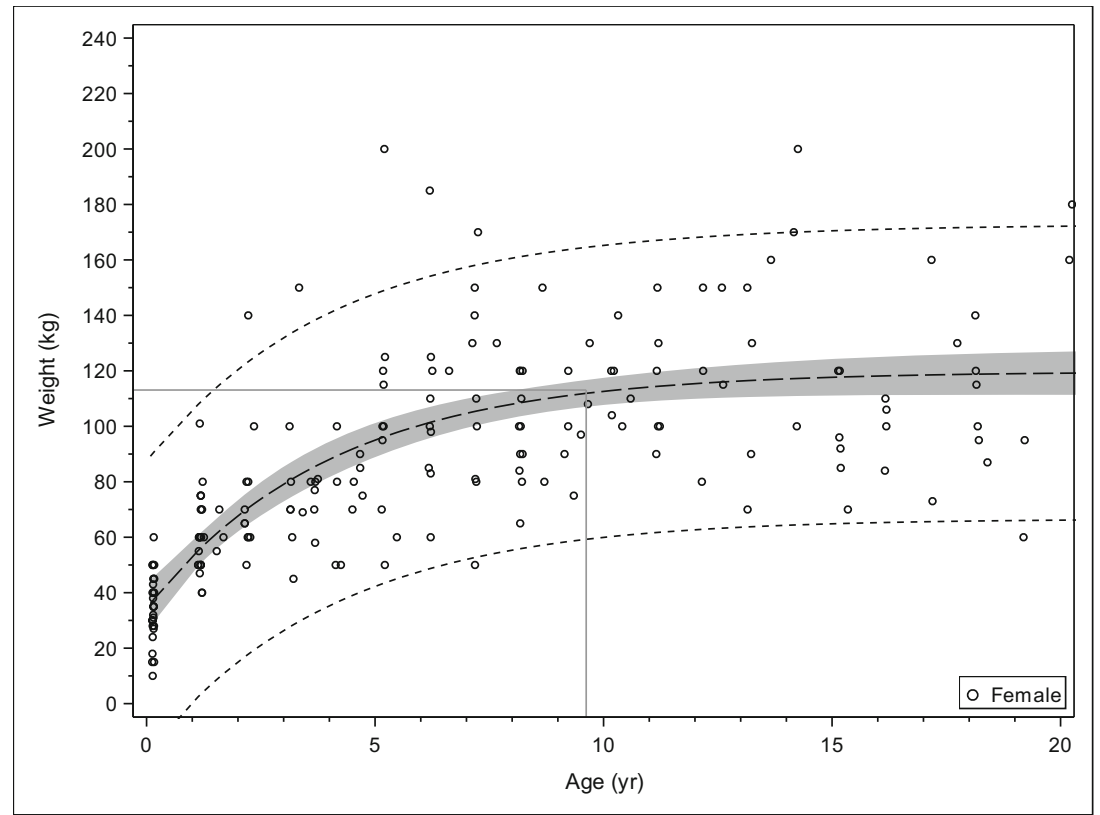

Males were bigger than females, probably due to sexual selection in a polygynous species. Males grew about to the age of 10 years, about the age when many of them start reproducing (Hewer 1964). Body length of females increased until the age of five. Females usually start reproduction between 5 and 7 years of age (Kauhala et al. 2014). These results suggest that seals grow until they start reproduction or vice versa, they start reproduction when they are almost fully grown (Boyd et al. 1999; Winship et al. 2001).
Males also gained weight to older age than females. Nursing is very costly to females which lose rapidly weight during the lactation period (Anderson and Fedak 1987). Therefore, they cannot put on much weight after they have started reproduction. The costs of reproduction are thus especially high for females (Boyd et al. 1995, 1999). However, also males invest heavily in reproduction, i.e. they invest in their body size. Big and heavy male seals may have better reproductive success than smaller ones (Anderson and Fedak 1985) because especially in polygynous mammals, big males 

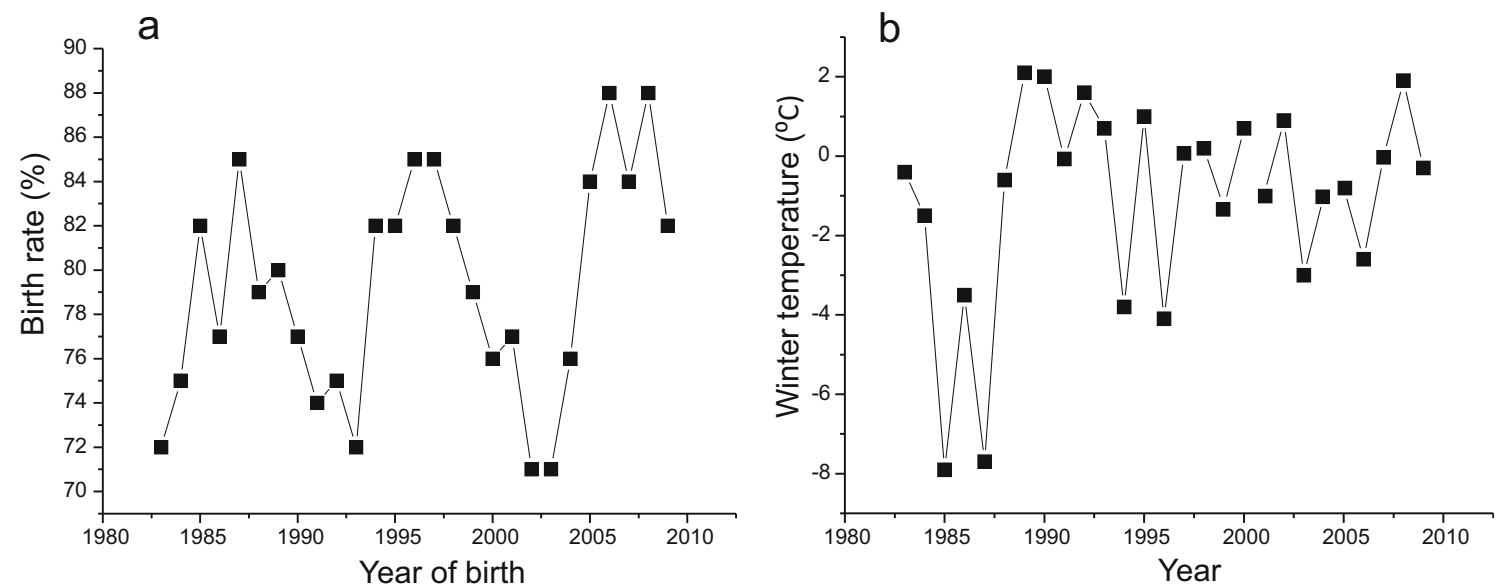

Fig. 6 Birth rate of 7-24-year-old females according to their birth year (a) and the mean temperatures of January-March in their birth year (Utö; b)

can successfully compete for females (Clutton-Brock et al. 1982; Anderson and Fedak 1987).

Birth year significantly explained the variation in the body length of adult males. This was connected to food quality in the birth year of seals, i.e. the mean weights of herring and sprat, which are important prey fish for Baltic grey seals (Lundström et al. 2010; Kauhala et al. 2011; Scharff-Olsen et al. 2018). It was shown earlier (Kauhala et al. 2017) that herring quality has an impact on body condition of grey seals, and the effect of food quality on body condition of especially male pups was confirmed in the present study. When fish quality is good, grey seal females are in good condition and can successfully nurse their pups. The nutritional status of females thus affects the amount of energy they can allocate to their pups (Lunn and Boyd 1993; Bowen et al. 2006). Food quality may also have a direct effect on pups after they have been weaned and start to forage for themselves. When food quality is good, pups are thus in good condition and grow faster, and males are bigger as adults than those born in years when food quality is poor. The declining adult length of male grey seals may, however, also be influenced by increasing population density which may affect body condition of females and their pups (Luke 2017; Harding et al. 2018). The numbers of grey seals in the Finnish sea area have not increased much in recent years suggesting that the population is approaching the carrying capacity of the environment.

Food quality in the birth year did not, however, affect the body length of female seals. Male pups are bigger, grow faster and need absolutely more energy than females (Anderson and Fedak 1987), and are thus the first to suffer malnutrition when food quality is poor. Male pups of Californian sea lions (Zalophus californianus californianus) were found to put more energy to growing than females (Luque and AuriolesGamboa 2001). Clutton-Brock et al. (1982) found that only male red deer (Cervus elaphus) calves suffered higher mortality when born in large groups, where competition for food may be heavy. Thus malnutrition as a pup can be seen later in the lives of especially males as a small size in adulthood.
Birth year had no significant effect on adult weight in grey seals. One reason may be small and inaccurate data for body weight. It is also likely that weight (and blubber thickness) is affected by food quality the present or the previous year, as found in earlier studies (Kauhala et al. 2016, 2017, 2019). In a capital breeder, such as the grey seal, body reserves the present year are thus also important for reproductive rate (Boyd 2000; Bowen et al. 2006).

Winter temperatures at the birth year of grey seal females had some influence on the birth rate later in their lives, although the connection between fish quality the present or previous year and the birth rate may be stronger (Kauhala et al. 2016, 2019). Blubber thickness of especially female pups correlated negatively with winter temperatures, and birth rate of females born in warm winters was lower than that of females born in cold winters. Furthermore, blubber thickness of pups decreased with declining ice cover in the Gulf of Finland (Kauhala et al. 2017). When winters are warm and there is little ice, females are forced to breed on land, which results in lower weaning weights of pups (Jüssi et al. 2008). In land (usually on small islets) there is more disturbance and pathogens spread easily compared with the situation when pups are born on drift ice and are scattered around the sea area. The low weight or poor body condition of pups may have delayed effects on their reproductive rate later in their lives (Boyd et al. 1999; Bowen et al. 2015), which may explain the connection between winter temperatures in the year of birth and birth rate of adult females.

\section{Conclusions}

Both food quality and winter temperatures have an influence on body condition of grey seal pups and may have delayed effects on body size and reproductive rate of adult grey seals. Our hypothesis was thus corroborated. Adult body size of males was related to food quality and birth rate of females to winter temperature at their birth year. Adult body size of males may also 
influence their reproductive success later in their lives. Thus, both changes in the food web affecting prey fish quality and climate warming may have delayed effects on the reproductive rate of Baltic grey seals, which, in turn, influences the growth rate of the population. More data and research are, however, needed to confirm the correlative connections found in the present study.

Acknowledgments We are grateful to all hunters and fishermen who sent seal samples to us. We also wish to thank M. Isomursu, M. Kunnasranta and P. Timonen for help in examining the samples. KK was financed by BONUS BaltHealth. The BaltHealth project has received funding from BONUS (Art. 185), funded jointly by the EU, Innovation Fund Denmark (grants 6180-00001B and 6180-00002B), Forschungszentrum Jülich $\mathrm{GmbH}$, German Federal Ministry of Education and Research (grant number FKZ 03F0767A), Academy of Finland (decision \#311966) and Swedish Foundation for Strategic Environmental Research.

Funding Information Open access funding provided by Natural Resources Institute Finland (LUKE).

\section{Appendix}

Table 2 The numbers of females (age 7-24) with corpus albicans (CA) and the total number of females of this age group born in different years

\begin{tabular}{|c|c|c|}
\hline Year & $\mathrm{CA}$ & $n$ \\
\hline 1983 & 3 & 5 \\
\hline 1984 & 9 & 11 \\
\hline 1985 & 3 & 4 \\
\hline 1986 & 11 & 13 \\
\hline 1987 & 9 & 13 \\
\hline 1988 & 13 & 13 \\
\hline 1989 & 15 & 21 \\
\hline 1990 & 13 & 17 \\
\hline 1991 & 20 & 24 \\
\hline 1992 & 16 & 25 \\
\hline 1993 & 16 & 20 \\
\hline 1994 & 18 & 24 \\
\hline 1995 & 34 & 39 \\
\hline 1996 & 31 & 38 \\
\hline 1997 & 31 & 36 \\
\hline 1998 & 16 & 18 \\
\hline 1999 & 16 & 23 \\
\hline 2000 & 9 & 11 \\
\hline 2001 & 13 & 16 \\
\hline 2002 & 11 & 16 \\
\hline 2003 & 13 & 20 \\
\hline 2004 & 12 & 15 \\
\hline 2005 & 6 & 6 \\
\hline 2006 & 8 & 10 \\
\hline 2007 & 7 & 8 \\
\hline 2008 & 6 & 7 \\
\hline 2009 & 1 & 1 \\
\hline 2010 & 2 & 3 \\
\hline
\end{tabular}

Open Access This article is distributed under the terms of the Creative Commons Attribution 4.0 International License (http:// creativecommons.org/licenses/by/4.0/), which permits unrestricted use, distribution, and reproduction in any medium, provided you give appropriate credit to the original author(s) and the source, provide a link to the Creative Commons license, and indicate if changes were made.

\section{References}

Anderson SS, Fedak MA (1985) Grey seal males: energetic and behavioural links between size and sexual success. Anim Behav 33:829838

Anderson SS, Fedak MA (1987) Grey seal, Halichoerus grypus, energetics: females invest more in male offspring. J Zool 211:667-679

Auttila M, Kurkilahti M, Niemi M, Levänen R, Sipilä T, Isomursu M, Koskela J, Kunnasranta M (2016) Morphometrics, body condition, and growth of the ringed seal (Pusa hispida saimensis) in Lake Saimaa: implications for conservation. Mar Mammal Sci 32:252267

Bäcklin BM, Moraeus C, Roos A, Eklöf E, Lind Y (2011) Health and age and sex distributions of Baltic grey seals (Halichoerus grypus) collected from bycatch and hunt in the Gulf of Bothnia. ICES J Mar Sci 68:183-188

Beckerman A, Benton TG, Ranta E, Kaitala V, Lundberg P (2002) Population dynamic consequences of delayed lite-history effects. Trends Ecol Evol 17:263-269

Bowen WD, Iverson SJ, McMillan JI, Boness DJ (2006) Reproductive performance in grey seals: age-related improvement and senescence in a capital breeder. J Anim Ecol 75:1340-1351

Bowen WD, den Heyer CE, McMillan JI, Iverson SI (2015) Offspring size at weaning affects survival to recruitment and reproductive performance of primiparous gray seals. Ecol Evol 5:1412-1424

Boyd IL (1984) Development and regression of the corpus luteum in grey seal (Halichoerus grypus) ovaries and its use in determining fertility rates. Can J Zool 62:1095-1100

Boyd IL (2000) State-dependent fertility in pinnipeds: contrasting capital and income breeders. Funct Ecol 14:623-630

Boyd IL, Croxall JP, Lunn NJ, Reid K (1995) Population demography of Antarctic fur seals: the costs of reproduction and implications for life-histories. J Anim Ecol 64:505-518

Boyd IL, Lockyer C, Marsh HD (1999) Reproduction in marine mammals. In: Reynolds JE, Rommel SA (eds) Biology of marine mammals. Smithsonian Institution Press, Washington

Cailliet GM, WD SHF, Mollet HF, Goldman KJ (2006) Age and growth studies of chondrichthyan fishes: the need for consistency in terminology, verification, validation and growth function fitting. Environ Biol Fish 77:211-228

Casini M, Cardinale M, Hjelm J (2006) Inter-annual variation in herring, Clupea harengus, and sprat, Sprattus sprattus, condition in the Central Baltic Sea: what gives the tune? Oikos 112:638-650

Casini M, Lövgren J, Hjelm J, Cardinale M, Molinero JC, Kornilovs G (2008) Multi-level trophic cascades in a heavily exploited open marine ecosystem. Proc R Soc B Biol Sci 275:1793-1801

Casini M, Bartolino V, Molinero JC, Kornilovs G (2010) Linking fisheries, trophic interactions and climate: threshold dynamics drive herring Clupea harengus growth in the Central Baltic Sea. Mar Ecol Prog Ser 413:241-252

Clutton-Brock TH, Guinness FE, Albon SD (1982) Red deer: behavior and ecology of two sexes. Edinburgh University press, Edinburgh

Descamps S, Boutin S, Berteaux D, McAdam AG, Gaillard JM (2007) Cohort effects in red squirrels: the influence of density, food abundance and temperature on future survival and reproductive success. J Anim Ecol 77:305-314 
Ferguson SH, Young BG, Yurkowski DJ, Anderson R, Willing C, Nielsen O (2017) Demographic, ecological, and physiological responses of ringed seals to an abrupt decline in sea ice availability. PeerJ 5: e2957. https://doi.org/10.7717/peerj.2957

Gårdmark A, Östman Ö, Nielsen A, Lundström K, Karlsson O, Pönni J, Aho T (2012) Does predation by grey seals (Halichoerus grypus) affect Bothnian Sea herring stock estimates? ICES J Mar Sci 69: $1448-1456$

Garrott RA, Rotella JJ, Siniff DB, Parkinson CL, Stauffer GE (2011) Environmental variation and cohort effects in an Antarctic predator. Oikos 121:1027-1040

Harding KC, Salmon M, Teilmann J, Dietz R, Harkonen T (2018) Population wide decline in somatic growth in harbor seals - early signs of density dependence. Front Ecol Evol 6. https://doi.org/10. 3389/fevo.2018.00059

Helle H, Koskela E, Mappes T (2012) Life in varying environments: experimental evidence for delayed effects of juvenile environment on adult life history. J Anim Ecol 81:573-582

Hewer HR (1964) The determination of age, sexual maturity, longevity and a life-table in the grey seal (Halichoerus grypus). Proc Zool Soc London 142:593-624

ICES (2018) Baltic Fisheries Assessment Working Group (WGBFAS), 6-13 April 2018, ICES HQ, Copenhagen, Denmark. 748 pp.

Jüssi M, Härkönen T, Helle E, Jüssi I (2008) Decreasing ice coverage will reduce the breeding success of Baltic grey seal (Halichoerus grypus) females. Ambio 37:80-85

Kauhala K, Kunnasranta M, Valtonen M (2011) Hallien ravinto Suomen merialueilla 2001-2007 - alustava selvitys (Summary: Diet of grey seals in Finland in 2001-2007 - a preliminary study). Suomen Riista 57:73-83 (in Finnish with English summary

Kauhala K, Ahola M, Kunnasranta M (2014) Decline in the pregnancy rate of Baltic grey seal females during the 2000s, estimated with different methods. Ann Zool Fenn 51:313-324

Kauhala K, Kurkilahti M, Ahola M, Herrero A, Karlsson O, Kunnasranta M, Tiilikainen R, Vetemaa M (2015) Age, sex and body condition of Baltic grey seals: are the problem seals a random sample of the population? Ann Zool Fenn 52:103-114

Kauhala K, Ahola M, Isomursu M, Raitaniemi J (2016) Impact of food resources, reproductive rate and hunting pressure on Baltic grey seal population in the Finnish sea area. Ann Zool Fenn 53:296-309

Kauhala K, Bäcklin BM, Harding K, Raitaniemi J (2017) The effect of prey quality and ice conditions on the nutritional status of Baltic gray seals of different age groups. Mammal Res 62:351-362

Kauhala K, Korpinen S, Lehtiniemi M, Raitaniemi J (2019) Reproductive rate of a top predator, the grey seal, as an indicator of the changes in the Baltic food web. Ecol Indic 102:693-703. https://doi.org/10. 1016/j.ecolind.2019.03.022

Lindström J (1999) Early development and fitness in birds and mammals. Trends Ecol Evol 14:343-348
Luke (2017) <https://www.luke.fi/tietoa-luonnonvaroista/riista/hylkeet/>

Lummaa V, Clutton-Brock T (2002) Early development, survival and reproduction in humans. Trends Ecol Evol 17:141-147

Lundström K, Hjerne O, Alexandersson K, Karlsson O (2007) Estimation of grey seal (Halichoerus grypus) diet composition in the Baltic Sea. Nammco Sci Publ 6:177-196

Lundström K, Hjerne O, Lunneryd SG, Karlsson O (2010) Understanding the diet composition of marine mammals: grey seals (Halichoerus grypus) in the Baltic Sea. ICES J Mar Sci 67:1230 1239

Lunn NJ, Boyd IL (1993) Effects of maternal age and condition on parturition and the perinatal period of Antarctic fur seals. J Zool 229: $55-67$

Luque SP, Aurioles-Gamboa D (2001) Sex differences in body size and body condition of California sea lion (Zalophus californianus californianus) pups from the Gulf of California. Mar Mammal Sci 17:147-160

Mansfield AW (1991) Accuracy of age determination in the grey seal Halichoerus grypus of eastern Canada. Mar Mammal Sci 7:44-49

McLaren IA (1993) Growth in pinnipeds. Biol Rev 68:1-79

Read AJ, Gaskin DE (1990) Changes in growth and reproduction of harbour porpoises, Phocoena phocoena, from the Bay of Fundy. Can J Fish Aquat Sci 47:2158-2163

Reid JM, Bignal EM, Bignal S, McCracken DI, Monaghan P (2003) Environmental variability, life-history covariation and cohort effects in the red-billed chough Pyrrhocorax pyrrhocorax. J Anim Ecol 72: $36-46$

Rödel HG, von Holst D, Kraus C (2009) Family legacies: short- and longterm fitness consequences of early-life conditions in female European rabbits. J Anim Ecol 78:789-797

Scharff-Olsen CH, Galatius A, Teilmann J, Dietz R, Andersen SM, Jarnit S, Kroner AM, Botnen AB, Lundström K, Møller PR, Olsen MT (2018) Diet of seals in the Baltic Sea region: a synthesis of published and new data from 1968 to 2013. ICES J Mar Sci. https://doi.org/10. 1093/icesjms/fsy159.doi:10.1093/icesjms/fsy159

Taborsky B (2006) Mothers determine offspring size in response to own juvenile growth conditions. Biol Lett 2:225-228

Tverin M, Esparza-Salas R, Strömberg A, Tang P, Kokkonen I, Herrero A, Kauhala K, Karlsson O, Ahola M, Tiilikainen R, Vetemaa M, Sinisalo T, Käkelä R, Lundström K (2019) Comparison of different methods assessing short and long-term prey of a marine top predator. PlosOne 14(1):e0208694. https://doi.org/10.1371/journal.pone. 0208694

Winship AJ, Trites AW, Calkins DG (2001) Growth in body size of the Steller sea lion (Eumetopias jubatus). J Mammal 82:500-519

Publisher's note Springer Nature remains neutral with regard to jurisdictional claims in published maps and institutional affiliations. 